\title{
Chronic wasting associated with Chlamydia pneumoniae in three ex situ breeding facilities for tropical frogs
}

\author{
Tobias Eisenberg (1) Ahmad Fawzy $\cdot$ Ute Kaim $\cdot$ Anne Nesseler $\cdot$ \\ Karin Riße · Iris Völker • Silke Hechinger • Nicole Schauerte $\cdot$ Christina Geiger • \\ Tobias Knauf-Witzens • Ingo Schwabe • Christiane Schnee • Elisabeth Liebler-Tenorio • \\ Can Imirzalioglu $\cdot$ Reinhard Sting
}

Received: 20 July 2020/Accepted: 13 October 2020/Published online: 5 November 2020

(C) The Author(s) 2020

\begin{abstract}
A number of different Chlamydia spp. have been detected in the class Amphibia with $C$. pneumoniae being the predominant species involved. Chlamydiae have been linked to mass mortality events, thereby representing significant pathogens that deserve attention with respect to worldwide amphibian decline. We here present six cases of chlamydiosis and asymptomatic chlamydial infections in different frog species from three ex situ amphibian conservation facilities. Clinical signs predominantly characterised by regurgitation, chronic wasting, lethargy and
\end{abstract}

T. Eisenberg $(\square) \cdot$ A. Fawzy · U. Kaim ·

A. Nesseler · K. Riße · I. Völker · S. Hechinger

Department of Veterinary Medicine, Hessian State

Laboratory (LHL), Schubertstr. 60, 35392 Giessen,

Germany

e-mail: tobias.eisenberg@1hl.hessen.de

T. Eisenberg

Institute of Hygiene and Infectious Diseases of Animals, Justus-Liebig-University Giessen, 35392 Giessen,

Germany

\section{A. Fawzy}

Faculty of Veterinary Medicine, Department of Medicine and Infectious Diseases, Cairo University, Cairo, Egypt

N. Schauerte - C. Geiger

Frankfurt Zoo, Bernhard-Grzimek-Allee 1,

60316 Frankfurt, Germany

T. Knauf-Witzens

Wilhelma - The Zoological and Botanical Gardens,

Wilhelma 13, 70376 Stuttgart, Germany suspended breeding were associated with C. pneumoniae infection. Despite various treatment regimens, it was not possible to clear infections. However, intra vitam diagnostics succeeded from skin, faeces and urine for the first time.

Keywords Chlamydia pneumoniae · Frog · Amphibian · Infectious disease $\cdot$ Zoonosis
I. Schwabe $\cdot$ R. Sting
Chemical and Veterinary Analysis Agency Stuttgart,
Schaflandstr. 3/3, 70736 Fellbach, Germany
C. Schnee $\cdot$ E. Liebler-Tenorio
Institute of Molecular Pathogenesis (IMP), Friedrich- Loeffler-Institut (FLI), Federal Research Institute for Animal Health, Naumburger Str. 96 a, 07743 Jena, Germany
C. Imirzalioglu
Justus Liebig University Giessen and German Center for Infection research (DZIF), Partner-site Giessen-Marburg- Langen, Institute for Medical Microbiology, Schubertstr. 81, 35392 Giessen, Germany 


\section{Introduction}

The genus Chlamydia is the sole genus in the family Chlamydiaceae and currently contains thirteen valid taxa (Borel and Greub 2019; Kuo et al. 2011; Sachse et al. 2015), although a novel genus, Chlamydophila, had transitionally been accepted between 1999 and 2015 (Everett et al. 1999). Besides traditional avian and mammalian hosts, chlamydiae are known to infect also poikilothermic vertebrates including fish, amphibians and reptiles (Borel et al. 2018; Homer et al. 1994; Huchzermeyer et al. 1994; Schindarow and Tonew 1965). Molecular techniques have facilitated detection of chlamydiae in various tissues. In contrast to clinical cases (chlamydiosis) such proofs especially query the significance and a supposed pathogenic potential in asymptomatic chlamydial infections. Recently, a number of candidate species have been proposed, but their formal description as valid species is still pending (Taylor-Brown et al. 2017).

Chlamydiosis in amphibians associated with a mass mortality event has first been described in a commercial breeding facility for African clawed frogs in the early 1980s (Newcomer et al. 1982). A Chlamydia sp. was identified as the causative agent of this mortality based on phenotypic methods including electron microscopy, immunofluorescence and cell culture (Newcomer et al. 1982; Wilcke et al. 1983). Although gross pathological lesions were largely missing, a representative strain from this outbreak turned out to be lethal for chicken embryos and naive frogs, but did not kill mice upon peritoneal inoculation (Wilcke et al. 1983). Pathological changes observed in a similar case also in African clawed frogs have been documented (Howerth 1984) and included hepatomegaly, distention of the gall bladder, splenomegaly, degenerative and inflammatory changes in the kidneys, epicarditis and myocarditis. In this mortality event, histopathology revealed mononuclear cell infiltrates and necrosis of hepatocytes in each necropsied frog, accompanied by occasional other changes of hepatocytes, reticuloendothelial cell proliferation, lymphoid depletion and spleen necrosis (Howerth 1984). However, types of inflammation varied greatly in histopathology between studies, among others including acute (Howerth 1984), lymphohistiocytic (Blumer et al. 2007), mononuclear (Newcomer et al. 1982) and lymphocytic to granulomatous (Reed et al. 2000) states. A complete overview of cases of amphibian chlamydioses from the literature is depicted in Table 1. Later, C. pneumoniae has been identified as causative agent of disease in amphibians (Berger et al. 1999; Bodetti et al. 2002; Fratzke et al. 2019; Reed et al. 2000) and confirmed by molecular methods (Berger et al. 1999). An Australian giant barred frog (Mixophyes iteratus) suffering from a severe, chronic, mononuclear pneumonia, non-regenerative anaemia and pancytopenia represents the first chlamydiosis case from the wild. This frog was found to be infected with a 'homeothermic ' $C$. pneumoniae strain giving rise to the question whether amphibians may play a role for zoonotic infections (Berger et al. 1999; Wright 1996). A further outbreak in African clawed frogs with significant morbidity and mortality due to $C$. pneumoniae was noted, but the most prominent clinical signslethargy, bloating and sloughing skin-might have been exacerbated by stress during importation and chytridiomycete co-infection (Reed et al. 2000). The majority of studies describes chlamydiae in anuran hosts (frogs), but urodelians (salamanders) were occasionally found to harbour not yet classified chlamydial species (Martel et al. 2012). Although all salamanders from three different species suffering from anorexia, lethargy, oedema and markedly abnormal gait died without any gross pathological lesions, a putatively novel member of the Chlamydiaceae most closely related to unclassified chlamydial species from fish and bullfrogs could be detected in liver tissue by 16S rRNA gene sequencing (Martel et al. 2012, 2013). Lastly, a retrospective case study from Switzerland had found other chlamydial species besides $C$. pneumoniae that were closely related to $C$. suis and $C$. abortus in a number of paraffin embedded tissue samples from native as well as exotic amphibians (Blumer et al. 2007). Another case series describes an exclusively neurotropic form of fatal $C$. pneumoniae infections in a breeding colony of endangered Houston toads (Anaxyrus houstonensis) in a zoological collection (Fratzke et al. 2019). Clinical signs included ataxia, anisocoria, and decreased righting reflex. Necrotising and histiocytic polioencephalomyelitis and ganglionitis were the major pathological findings and chlamydial inclusions were found within and in the surrounding of neurons (Fratzke et al. 2019). In addition, infections with members of the Parachlamydiaceae (genera Parachlamydia Bates et al. 2018; Vajana et al. 2019 and Neochlamydia Vajana et al. 
Table 1 Case series presentation of chlamydial infections in amphibians from the literature

\begin{tabular}{|c|c|c|c|c|c|c|c|}
\hline $\begin{array}{l}\text { Case } \\
\text { no. }\end{array}$ & Amphibian species & $\begin{array}{l}\text { No. of } \\
\text { animals } \\
\text { involved }\end{array}$ & $\begin{array}{l}\text { Country } \\
\text { (infection } \\
\text { noticed in the } \\
\text { wild [w] or in } \\
\text { captivity [c]) }\end{array}$ & $\begin{array}{l}\text { Tissues with } \\
\text { chlamydial proof }\end{array}$ & Chlamydial species & Year & Source \\
\hline 01 & $\begin{array}{l}\text { African clawed frog } \\
\text { (Xenopus laevis) }\end{array}$ & 20.000 & USA (c) & $\begin{array}{l}\text { Liver, spleen, } \\
\text { kidney, lung, } \\
\text { heart }\end{array}$ & "C. psittaci" & 1982 & $\begin{array}{l}\text { Newcomer } \\
\text { et al. } \\
\text { (1982), } \\
\text { Wilcke } \\
\text { et al. (1983) }\end{array}$ \\
\hline 02 & $\begin{array}{l}\text { African clawed frog } \\
\text { (Xenopus laevis) }\end{array}$ & 6 & USA (c) & $\begin{array}{l}\text { Liver, spleen, } \\
\text { kidney, heart }\end{array}$ & "C. psittaci" & 1984 & $\begin{array}{c}\text { Howerth } \\
(1984)\end{array}$ \\
\hline 03 & $\begin{array}{l}\text { Eyelash leaf frogs } \\
\text { (Cornufer } \\
\text { [Ceratobatrachus] } \\
\text { guentheri) }\end{array}$ & 8 & $\begin{array}{l}\text { Canada, } \\
\text { imported } \\
\text { from } \\
\text { Salomon } \\
\text { Islands (w) }\end{array}$ & $\begin{array}{l}\text { Liver, spleen, } \\
\text { kidney, lung, } \\
\text { heart, muscle, } \\
\text { fat tissue, } \\
\text { medulla }\end{array}$ & Chlamydia sp. & 1992 & $\begin{array}{l}\text { Honeyman } \\
\text { et al. (1992) }\end{array}$ \\
\hline 04 & $\begin{array}{l}\text { Xenopus laevis, } \\
\text { „Bufo } \\
\text { maculatum“, } \\
\text { Pachytriton sp. }\end{array}$ & 15 & Germany, (c) & $\begin{array}{l}\text { Liver, spleen, } \\
\text { kidney, lung, } \\
\text { heart, blood } \\
\text { cells }\end{array}$ & "C. psittaci" & 1998 & $\begin{array}{l}\text { Mutschmann } \\
\text { (1998) }\end{array}$ \\
\hline 05 & $\begin{array}{l}\text { Giant barred frog } \\
\text { (Mixophyes } \\
\text { iteratus) }\end{array}$ & 1 & Australia, (w) & Lung, blood & C. pneumoniae & 1999 & $\begin{array}{l}\text { Berger et al. } \\
\text { (1999) }\end{array}$ \\
\hline 06 & $\begin{array}{l}\text { African clawed frog } \\
\text { (Xenopus } \\
\text { tropicalis) }\end{array}$ & 220 & $\begin{array}{l}\text { USA, imported } \\
\text { from West } \\
\text { Africa (c) }\end{array}$ & Liver & C. pneumoniae & 2000 & $\begin{array}{l}\text { Reed et al. } \\
\text { (2000) }\end{array}$ \\
\hline 07 & $\begin{array}{l}\text { Blue Mountains tree } \\
\text { frogs (Litoria } \\
\text { citropa) }\end{array}$ & 2 & Australia (c) & $\begin{array}{l}\text { Kidney, heart, } \\
\text { lung, } \\
\text { gastrointestinal } \\
\text { tract, brain }\end{array}$ & C. pneumoniae & 2002 & $\begin{array}{l}\text { Bodetti et al. } \\
\text { (2002) }\end{array}$ \\
\hline 08 & $\begin{array}{l}\text { Cryptohylax } \\
\text { gresshoffi }\end{array}$ & 3 & $\begin{array}{l}\text { Central } \\
\text { African } \\
\text { Republic (w; } \\
\text { [Germany]) }\end{array}$ & $\begin{array}{l}\text { Liver, spleen, } \\
\text { kidney }\end{array}$ & C. pneumoniae & 2001 & $\begin{array}{l}\text { Hotzel et al. } \\
\text { (2001) }\end{array}$ \\
\hline 09 & $\begin{array}{l}\text { Rana temporaria } \\
\text { (mass mortality } \\
\text { 1991/1992) }\end{array}$ & $\begin{array}{l}8 \text { out of } 54 \\
\text { samples } \\
\text { (no. of } \\
\text { individuals } \\
\text { unknown) }\end{array}$ & $\begin{array}{l}\text { Switzerland } \\
\text { (w) }\end{array}$ & $\begin{array}{l}\text { Kidney, spleen, } \\
\text { liver }\end{array}$ & $\begin{array}{l}\text { "C. suis" } \\
\text { (98-99\% homology) }\end{array}$ & 2007 & $\begin{array}{l}\text { Blumer et al. } \\
\text { (2007) }\end{array}$ \\
\hline 10 & $\begin{array}{l}\text { Various species } \\
\text { (sudden deaths in } \\
\text { zoos/private } \\
\text { collections }\end{array}$ & $\begin{array}{l}3 \text { out of } 83 \\
\text { samples } \\
\text { (no. of } \\
\text { individuals } \\
\text { unknown) }\end{array}$ & Switzerland (c) & $\begin{array}{l}\text { Kidney, spleen, } \\
\text { liver }\end{array}$ & C. pneumoniae & 2007 & $\begin{array}{l}\text { Blumer et al. } \\
\text { (2007) }\end{array}$ \\
\hline 11 & $\begin{array}{l}\text { Xenopus laevis } \\
\text { (healthy control) }\end{array}$ & $\begin{array}{l}3 \text { out of } 38 \\
\text { samples } \\
(\mathrm{n}=19 \\
\text { individuals) }\end{array}$ & Switzerland (c) & $\begin{array}{l}\text { Kidney, spleen, } \\
\text { liver }\end{array}$ & $\begin{array}{l}2 \times{ }^{\circ C} \text {. suis" } \\
(98-99 \% \text { homology), } \\
1 \times \text { endosymbiont of } \\
\text { Acanthamoeba } \text { sp. }\end{array}$ & 2007 & $\begin{array}{l}\text { Blumer et al. } \\
\text { (2007) }\end{array}$ \\
\hline
\end{tabular}


Table 1 continued

\begin{tabular}{|c|c|c|c|c|c|c|c|}
\hline $\begin{array}{l}\text { Case } \\
\text { no. }\end{array}$ & Amphibian species & $\begin{array}{l}\text { No. of } \\
\text { animals } \\
\text { involved }\end{array}$ & $\begin{array}{l}\text { Country } \\
\text { (infection } \\
\text { noticed in the } \\
\text { wild [w] or in } \\
\text { captivity [c]) }\end{array}$ & $\begin{array}{l}\text { Tissues with } \\
\text { chlamydial proof }\end{array}$ & Chlamydial species & Year & Source \\
\hline 12 & $\begin{array}{l}\text { Rana temporaria } \\
(2004 / 2005)\end{array}$ & $\begin{array}{l}6 \text { out of } 238 \\
\text { samples } \\
(\mathrm{n}=126 \\
\text { individuals) }\end{array}$ & $\begin{array}{l}\text { Switzerland } \\
\text { (w) }\end{array}$ & $\begin{array}{l}\text { Kidney, spleen, } \\
\text { liver }\end{array}$ & $\begin{array}{l}\text { "C. suis" } \\
\text { (98-99\% homology), } \\
1 \times \text { C. pneumoniae, } \\
3 \times \text { C. abortus, } 1 \times \\
\text { uncultured } \\
\text { Chlamydiales }\end{array}$ & 2007 & $\begin{array}{l}\text { Blumer et al. } \\
(2007)\end{array}$ \\
\hline 13 & $\begin{array}{l}\text { Salamandra corsica } \\
\text { (Corsican fire } \\
\text { salamander) }\end{array}$ & 5 & $\begin{array}{l}\text { The } \\
\text { Netherlands/ } \\
\text { Germany (c) }\end{array}$ & Liver & $\begin{array}{l}\text { 'Candidatus } \\
\text { Amphibiichlamydia } \\
\text { salamandrae' }\end{array}$ & 2012 & $\begin{array}{l}\text { Martel et al. } \\
\text { (2012) }\end{array}$ \\
\hline 14 & $\begin{array}{l}\text { Neurergus crocatus } \\
\text { (yellow spotted } \\
\text { newt) }\end{array}$ & $\begin{array}{l}11 \text { (from } 3 \\
\text { collections) }\end{array}$ & $\begin{array}{l}\text { The } \\
\text { Netherlands/ } \\
\text { Germany (c) }\end{array}$ & Liver & $\begin{array}{l}\text { 'Candidatus } \\
\text { Amphibiichlamydia } \\
\text { salamandrae' }\end{array}$ & 2012 & $\begin{array}{l}\text { Martel et al. } \\
\text { (2012) }\end{array}$ \\
\hline 15 & $\begin{array}{l}\text { Neurergus strauchii } \\
\text { (Strauch's spotted } \\
\text { newt) }\end{array}$ & $\begin{array}{l}6 \text { (from } 2 \\
\text { collections) }\end{array}$ & $\begin{array}{l}\text { The } \\
\text { Netherlands/ } \\
\text { Germany (c) }\end{array}$ & Liver & $\begin{array}{l}\text { 'Candidatus } \\
\text { Amphibiichlamydia } \\
\text { salamandrae' }\end{array}$ & 2012 & $\begin{array}{l}\text { Martel et al. } \\
\text { (2012) }\end{array}$ \\
\hline 16 & $\begin{array}{l}\text { Lithobates } \\
\text { catesbeianus } \\
\text { (North American } \\
\text { bullfrog tadpoles) }\end{array}$ & $\begin{array}{l}\text { No clinical } \\
\text { signs (71\% } \\
\text { prevalence) }\end{array}$ & $\begin{array}{l}\text { The } \\
\text { Netherlands } \\
\text { (w; } \\
\text { introduced } \\
\text { population) }\end{array}$ & Liver & $\begin{array}{l}\text { 'Candidatus } \\
\text { Amphibiichlamydia } \\
\text { ranarum' }\end{array}$ & 2013 & $\begin{array}{l}\text { Martel et al. } \\
\text { (2013) }\end{array}$ \\
\hline 17 & $\begin{array}{l}\text { Anaxyrus } \\
\text { houstonensis } \\
\text { (Houston toad) }\end{array}$ & 175 & USA (c) & Brain, (liver) & C. pneumoniae & 2019 & $\begin{array}{l}\text { Fratzke et al. } \\
\text { (2019) }\end{array}$ \\
\hline
\end{tabular}

2019) and Simkaniaceae (Vajana et al. 2019) have occasionally been reported.

In the present study, we have compiled clinical data on chlamydial infections in amphibians from the literature with those from own actual cases. The data of the present study was obtained from frogs mostly developing clinically signs, however, this was not a designed study. Therefore, the available data vary from case to case and could not be consistently collected. Even so, cluster of cases in tropical frog holdings attracting attention by clinical, pathological, histological and microbiological findings and the presence of chlamydiae in organ samples advocate that these pathogens have the potential to impair the health of amphibians. The scope of the present study was to report the detection of chlamydiae in tropical frogs suffering from debilitating disease. We argue that rather non-specific behavioural abnormities have to be taken into consideration that finally led to the loss of valuable breeding groups of endangered amphibian species.

\section{Materials and methods}

Collections and animals

Observations described in this manuscript were made on animals from three different holdings, namely one private collection and two zoos, designated as zoo A and zoo B, respectively. Each of the groups of frogs was housed in a terrarium $(60 \times 65 \times 120 \mathrm{~cm}$; LxWxH), densely planted with tropical vegetation. Maintenance conditions included a twelve-hour night/day interval with temperatures between 20 and $27^{\circ} \mathrm{C}$ during the day unless otherwise stated. An automatic sprinkling system was used to achieve a relative humidity above $70 \%$.

The private collection comprised five captive-bred approx. 4-year old coronated tree frogs, Triprion (Anotheca) spinosus, originally imported from Costa Rica housed together with eight lemur leaf frogs (Agalychnis lemur). The Triprion group was later transferred to the quarantine unit of zoo B. 
Additionally, there was a second terrarium with a group of eight captive-bred, 3-year old fringed leaf frogs (Cruziohyla craspedopus), originally imported from Peru. A third terrarium contained a group of 17 captive-bred 1-3-year old casque-headed treefrogs (Triprion petasatus). All three terraria were standing directly next to each other, but drains were closed off each by a turncock to prevent wastewater bypass. The Triprion petasatus terrarium was further equipped with an additional ultraviolet and heating device (Bright Sun, $50 \mathrm{~W}$, Lucky Reptile, Germany) to achieve daytime maximum temperatures of up to $35{ }^{\circ} \mathrm{C}$. In zoos A and B, each a group of White's tree frogs, Ranoidea (Litoria) caerulea, and long-nosed horned frogs (Megophrys nasuta), 2 females and one male, were kept without any clinical abnormalities under the same conditions like in the private collection. Zoo B also took over the group of Triprion spinosus from the private collection.

All the mentioned frog species of the three collections were initially checked during quarantine and when abnormalities were observed by specific qPCRs for the presence of Batrachochytrium dendrobatidis, B. salamandrivorans, ranavirus, Brucella spp. and by faecal examination for parasites and yielded-except for the Strongyloides sp.- only negative results (data not shown).

Necropsy and histopathology

A full necropsy was performed on deceased frogs from this study. For histopathological examination, small slices of multiple organs were fixed in buffered $4 \%$ formalin, processed by standard methods and embedded in paraffin. Sections were stained with hematoxylin-eosin (HE). Additional sections were further processed for Chlamydia-specific immuno-histochemistry (IHC). Briefly, chlamydiae were detected by the indirect immunoperoxidase method. Tissues examined included skin, muscle, bone, eye, brain, heart, lung, liver, spleen, kidney, intestine, mesothelium, testis and ovary. For antigen retrieval, slides were incubated in $0.025 \%$ proteinase $\mathrm{K}$ (Sigma, Taufkirchen, Germany) in phosphate buffered saline ( $\mathrm{pH}$ 7.4) for $5 \mathrm{~min}$ at $37^{\circ} \mathrm{C}$. A monoclonal antibody against Chlamydia-LPS (ACIP500, Progen Biotech $\mathrm{GmbH}$, Heidelberg, Germany) was used as primary antibody, HRP-conjugated goat anti-mouse immunoglobulins (Agilent Dako Products,
Waldbronn, Germany) as secondary antibody and 3-amino-9-ethlycarbazole as chromogen. Sections were counterstained with hemalaun.

Chlamydial culture and bacterial cultivation from clinical samples

For chlamydia isolation, buffalo green monkey (BGM) cells in Eagle's Minimal Essential Medium (EMEM, Lonza, Basel, Switzerland) with $2 \mathrm{mmol}$ glutamine and 5\% fetal calf serum were seeded into Trac bottles with coverslips (Sterilin, Thermo Fisher, Dreieich, Germany) and incubated at $37{ }^{\circ} \mathrm{C}$ with $5 \%$ $\mathrm{CO}_{2}$ for 3-4 days. Tissue samples from liver, spleen and kidney were homogenised and ultrasonicated in 2-5 mL SPGA (sucrose-phosphate-glutamine-albumine) stabilising buffer. After a 15 min centrifugation at $500 \times g, 30-300 \mu \mathrm{L}$ of the supernatants were inoculated into 4-6 Track bottles and centrifuged at $3400 \times g$ at $37{ }^{\circ} \mathrm{C}$ for $60 \mathrm{~min}$. The bottles were incubated for $2 \mathrm{~h}$ and EMEM was replaced by serumfree UMDCK medium (Lonza) with an antibiotic cocktail containing nystatin, gentamicin and vancomycin. Medium was renewed after $18 \mathrm{~h}$. Two to 3 days after inoculation, the coverslips were fixed with methanol and cells were stained with fluorescencelabeled monoclonal antibodies from the IMAGEN Chlamydia kit (Oxoid).

Samples from living frogs (skin swabs, faeces, urine, cloacal washings) or various tissue samples (liver, spleen, kidney, lung, ovary, intestine, skin and in one case intraocular fluid) obtained during necropsies were directly cultured on 5\% Columbia sheep blood (SBA) and water-blue metachrome-yellow lactose agar according to Gassner (all Oxoid, Wesel, Germany) at $20^{\circ} \mathrm{C}$ aerobically for up to $48 \mathrm{~h}$. Concomitant bacterial isolates were identified by MALDI-TOF mass spectrometry (MALDI-TOF MS, Bruker Biotyper, Bruker Daltonik, Bremen, Germany). Tissue samples were also inoculated onto Brucella selective media (with and without crystal violet [Oxoid]) as well as in enrichment broth for the isolation of Salmonella.

Chlamydia detection by PCR and phylogenetic analysis

For the molecular detection of chlamydiae, $250 \mathrm{mg}$ tissue samples as mentioned above for bacterial 
cultivation were homogenised in $1 \mathrm{~mL}$ of phosphate buffered saline (PBS, Oxoid) using a FastPrep-24 Classic bead beating grinder and Lysing Matrix tubes with ceramic beads (MP Biomedicals, Eschwege, Germany). Homogenates were centrifuged briefly to sediment tissue fragments and DNA was extracted from $200 \mu \mathrm{L}$ supernatant via IndiMag Pathogen Kit on the IndiMag 48 Magnetic bead based nucleic acid extractor (Indical, Leipzig, Germany) according to the manufacturer's instructions.

Detection of chlamydial DNA was carried out by qPCR according to (Anonym 2020) based on the 23S rRNA gene (genus level), whereas Chlamydia typing was performed with a commercial qPCR assay (Allplex RP-4, Seegene, Germany) based on the murB gene (species level $C$. pneumoniae). An almost fulllength 16S rRNA gene ( $>1500 \mathrm{bp})$ was amplified using the primers $16 \mathrm{~S} \quad \mathrm{~F}$ (5'GCGTGGATGAGGCATGCAA'3) and $16 \mathrm{~S}$ R (5'GGAGGTGATCCAGCCCCA' 3 ) described by Everett (2000). The PCR reaction $(25 \mu \mathrm{L})$ consisted of $12.5 \mu \mathrm{L} 2 \mathrm{X}$ Platinum $^{\mathrm{TM}}$ SuperFi $^{\mathrm{TM}}$ PCR Master Mix (Thermo Fisher Scientific, Germany), $1.25 \mu \mathrm{L}$ $16 \mathrm{~S} F$ primer $(10 \mu \mathrm{M}), 1.25 \mu \mathrm{L} 16 \mathrm{~S} \quad \mathrm{R}$ primer $(10 \mu \mathrm{M}), 5 \mu \mathrm{L}$ PCR water and $5 \mu \mathrm{L}$ DNA. Cycling conditions were as following: $1 \times\left(98{ }^{\circ} \mathrm{C}-30 \mathrm{~s}\right) 45 \times$ $\left(98{ }^{\circ} \mathrm{C}-10 \mathrm{~s} ; 65^{\circ} \mathrm{C}-10 \mathrm{~s} ; 72{ }^{\circ} \mathrm{C}-90 \mathrm{~s}\right) 1 \times\left(72{ }^{\circ} \mathrm{C}-\right.$ $5 \mathrm{~min})$. PCR products were sent to Seqlab-Microsynth laboratories (Göttingen, Germany) for DNA purification and sequencing.

Using the sequence obtained in this study together with homologues of other Chlamydia species, we carried out a phylogenetic analysis with PhyML (Maximum-Likelihood algorithm, 100 bootstraps, http://www.phylogeny.fr/one_task.cgi?task_type= phyml) under default conditions (Dereeper et al. 2008). For an overview of the different diagnostic approaches employed for chlamydial identification at genus or species level in this as well as in comparable earlier studies the reader is referred to Table 2 .

Further testing

Skin and liver or kidney samples were tested for the presence of chytrid fungi (Batrachochytrium [B.] dendrobatidis, $B$. salamandrivorans) and ranavirus by PCR, respectively, employing previously published protocols (Black et al. 2017; Boyle et al. 2004).

\section{Results}

Case history, clinical and pathological observations

1. Private collection:

Triprion (Anotheca) spinosus and Agalychnis lemur: The group of coronated treefrogs regularly laid fertilised clutches until summer 2018. Whereas the lemur leaf frogs did not show any clinical signs or abnormalities, the Triprion group stopped calling and breeding, lost their bright skin colouration and developed a faded and dry skin with regular ecdysis and consistently regurgitated insect prey items within $48 \mathrm{~h}$ of feeding. At this stage, the group was transferred to the quarantine unit of zoo B in February 2019 in order to improve breeding success.

Cruziohyla craspedopus: The group regularly laid fertilised clutches until summer 2018. Similarly, frogs stopped calling and breeding with no externally visible signs like weight loss and skin abnormalities, except sporadically regurgitating insect prey items. All animals survived but without any breeding success.

Triprion petasatus: As these frogs are very seasonal, calling cannot be observed throughout the year and cannot be exploited for assessment of clinical disease status. Breeding could be induced every year. The group was active, but often regurgitated insect prey items since summer 2018 and emaciated significantly. However, the group also contained subjects with an adipose nutritional status. All these frogs were still active at night. Ten frogs died, but only two were available for post mortem examinations due to highgrade decomposition; the rest of the animals survived. A low-grade nematode infestation with Strongyloides sp. was noted which turned out to be refractory to oral levamisole and ivermectin treatment regimens (data not shown).

\section{Zoo A:}

Ranoidea (Litoria) caerulea: During 2016 and 2017, 13 White's tree frogs died. Prior to death, three animals displayed clinical signs including emaciation, oedema on legs and abdomen, neurological signs, and bloating (Table 3 ). 
Table 2 Diagnostic methods used for the detection of chlamydial infections in amphibians from the literature and from this study

\begin{tabular}{|c|c|c|c|c|c|c|c|c|c|c|}
\hline Case no. & Amphibian species & Histo $^{1}$ & $\mathrm{IHC}^{2}$ & $\mathrm{IF}^{3}$ & $\mathrm{TEM}^{4}$ & $\mathrm{LPS}^{5}$ & $\mathrm{CC}^{6}$ & $\mathrm{ECE}^{7}$ & $\mathrm{MIT}^{8}$ & $16 \mathrm{~S}^{9}$ \\
\hline 01 & Xenopus laevis & $\mathrm{X}$ & & $\mathrm{x}$ & $\mathrm{x}$ & & $\mathrm{x}$ & $\mathrm{x}$ & $\mathrm{x}$ & \\
\hline 02 & Xenopus laevis & $\mathrm{x}$ & & & $\mathrm{x}$ & & & & & \\
\hline 03 & Cornufer (Ceratobatrachus) guentheri & $\mathrm{x}$ & & & $\mathrm{x}$ & & & & & \\
\hline 04 & Xenopus laevis, „Bufo maculatum“, Pachytriton sp. & $\mathrm{x}$ & & $\mathrm{x}$ & & & & & & \\
\hline 05 & Mixophyes iteratus & $\mathrm{x}$ & & $\mathrm{x}$ & $\mathrm{x}$ & $\mathrm{x}$ & $\mathrm{x}$ & & & $\mathrm{x}$ \\
\hline 06 & Xenopus tropicalis & $\mathrm{x}$ & & $\mathrm{x}$ & $\mathrm{x}$ & & $\mathrm{x}$ & & & $\mathrm{x}$ \\
\hline 07 & Litoria citropa & $\mathrm{x}$ & $\mathrm{x}$ & $\mathrm{x}$ & & & & & & $\mathrm{x}$ \\
\hline 08 & Cryptohylax gresshoffi & $\mathrm{x}$ & & $\mathrm{x}$ & & & $\mathrm{x}$ & & & $\mathrm{x}$ \\
\hline 09 & Rana temporaria & $\mathrm{x}$ & $\mathrm{x}$ & & & & & & & $\mathrm{x}$ \\
\hline 10 & Various species & $\mathrm{x}$ & $\mathrm{x}$ & & & & & & & $\mathrm{x}$ \\
\hline 11 & Xenopus laevis & $\mathrm{x}$ & $\mathrm{x}$ & & & & & & & $\mathrm{x}$ \\
\hline 12 & Rana temporaria & $\mathrm{x}$ & $\mathrm{x}$ & & & & & & & $\mathrm{x}$ \\
\hline 13 & Salamandra corsica & & $\mathrm{x}$ & & $\mathrm{x}$ & & & & & $\mathrm{x}$ \\
\hline 14 & Neurergus crocatus & & $\mathrm{x}$ & & $\mathrm{x}$ & & & & & $\mathrm{x}$ \\
\hline 15 & Neurergus strauchii & & $\mathrm{x}$ & & $\mathrm{x}$ & & & & & $\mathrm{x}$ \\
\hline 16 & Lithobates catesbeianus & & & $\mathrm{x}$ & & & & & & $\mathrm{x}$ \\
\hline 17 & Anaxyrus houstonensis & $\mathrm{x}$ & & & $\mathrm{x}$ & & $\mathrm{x}$ & & & \\
\hline 18 & Ranoidea (Litoria) caerulea & $\mathrm{x}$ & $\mathrm{x}$ & & & & & & & \\
\hline 19 & Triprion (Anotheca) spinosus & $\mathrm{x}$ & $\mathrm{x}$ & & & & $\mathrm{x}$ & & & $\mathrm{x}$ \\
\hline 20 & Agalychnis lemur & $\mathrm{x}$ & & & & & & & & \\
\hline 21 & Cruziohyla craspedopus & $\mathrm{x}$ & & & & & & & & \\
\hline 22 & Triprion petasatus & $\mathrm{x}$ & & & & & $\mathrm{x}$ & & & \\
\hline 23 & Megophrys nasuta & $\mathrm{x}$ & & & & & & & & \\
\hline $\begin{array}{l}\text { Case } \\
\text { no. }\end{array}$ & 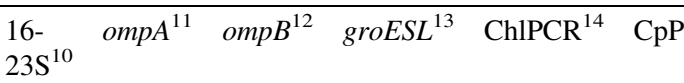 & $\mathrm{CR}^{15}$ & $\mathrm{CsPCR}^{16}$ & & & $\mathrm{PCR}^{18}$ & Sourc & & & \\
\hline
\end{tabular}

$$
01
$$

02

03

04

$\begin{array}{lllll}05 & & \mathrm{x} & \mathrm{x} & \\ 06 & & \mathrm{x} & & \\ 07 & & \mathrm{x} & & \\ 08 & \mathrm{x} & \mathrm{x} & \mathrm{x} & \mathrm{x} \\ 09 & & \mathrm{x} & & \\ 10 & & \mathrm{x} & & \\ 11 & & \mathrm{x} & & \\ 12 & & \mathrm{x} & & \end{array}$

14

15

16

17

18

Newcomer et al. (1982), Wilcke et al. (1983)

Howerth (1984)

Honeyman et al. (1992)

Mutschmann (1998)

Berger et al. (1999)

Reed et al. (2000)

Bodetti et al. (2002)

Hotzel et al. (2001)

Blumer et al. (2007)

Blumer et al. (2007)

Blumer et al. (2007)

Blumer et al. (2007)

Martel et al. (2012)

Martel et al. (2012)

Martel et al. (2012)

Martel et al. (2013)

Fratzke et al. (2019)

$\mathrm{X}$

This study 
Table 2 continued

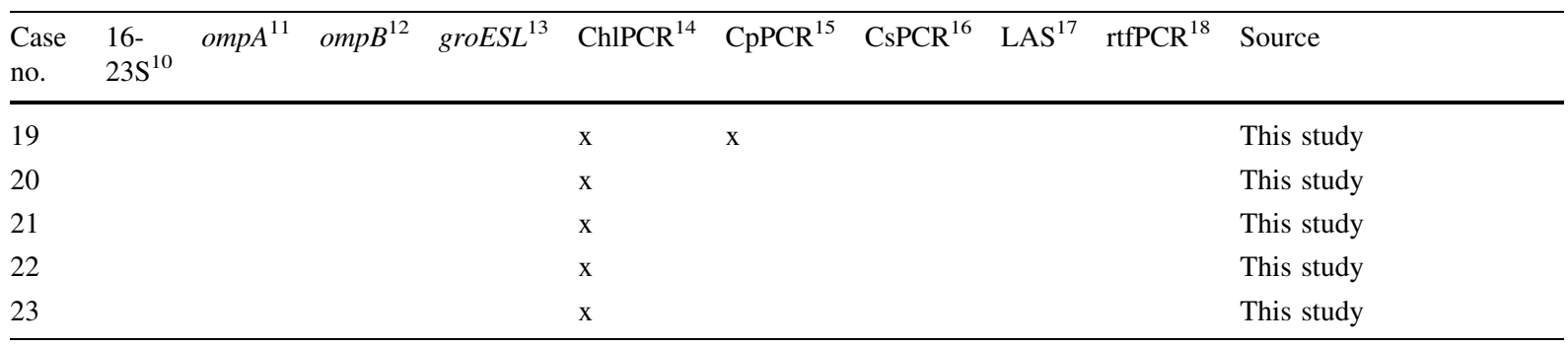

${ }^{1}$ Histology; ${ }^{2}$ immuno-histochemistry; ${ }^{3}$ direct immunofluorescence; ${ }^{4}$ transmission electron-microscopy; ${ }^{5}$ LPS antigen detection assay; ${ }^{6}$ cell culture; ${ }^{7}$ embryonated chicken eggs; ${ }^{8}$ mouse inoculation test; ${ }^{9} 16 \mathrm{~S}$ rRNA gene; ${ }^{10}$ 16-23S intergenic spacer genes; ${ }^{11}$ ompA gene sequencing; ${ }^{12}$ omp B gene sequencing; ${ }^{13}$ groESL gene sequencing; ${ }^{14}$ Chlamydia spp. qPCR; ${ }^{15}$ C. pneumoniae PCR; ${ }^{16}$ C. suis PCR; ${ }^{17}$ laser capture microdissection; ${ }^{18}$ real-time fluorescence resonance energy transfer PCR

\section{Zoo B:}

Triprion spinosus: During quarantine between March and May 2019, three of the frogs originating from the private collection died. The two remaining frogs displayed wasting, emaciated nutritional status. Despite antimicrobial therapy as described below they finally died nonetheless two to 3 weeks later.

Megophrys nasuta: Two adult females were suddenly found dead one at a time on different days. They did not show any conspicuous clinical signs prior to death as was the case for the remaining male individual from the same breeding group.

Available background information on the cases from this study as well as previous, comparable infection events are summarised in Tables 1, 2, 3 and 4.

\section{Treatment}

In zoo B, parenteral treatments were initiated in the coronated tree frogs during first Chlamydia proofs within the quarantine period. For this purpose, injections with enrofloxacin (Baytril 2.5\%, Bayer, Leverkusen, Germany) into the dorsal lymph sac at $5 \mathrm{mg} /$ $\mathrm{kg} \mathrm{SC} \mathrm{q} 24 \mathrm{~h}$ were conducted. In the private collection, treatment baths were initially (in March 2019) carried out to treat Agalychnis lemur, Cruziohyla craspedopus and Triprion petasatus with tetracycline (Ursocyclin, Serumwerk Bernburg, Bernburg, Germany; $100 \mathrm{mg} / \mathrm{L}$ for $60 \mathrm{~min} \mathrm{q} 24 \mathrm{~h}$ for 12 days) and subsequently - due to repeated pathogen detection in April 2019-with enrofloxacin (Enro-Sleecol, Dechra, Aulendorf, Germany; $500 \mathrm{mg} / \mathrm{L}$ for $6 \mathrm{~h} \mathrm{q} 24 \mathrm{~h}$ for 12 days).
Immuno-histochemistry

By IHC, chlamydial inclusions were detected in tissues of Triprion spinosus from zoo B, but not in tissues of Litorea caerulea from zoo A. One of the four Triprion spinosus examined had chlamydial inclusions in the skin, the kidney and the intestine, and one each in the kidney and the lung only. In all of these tissues, few chlamydial inclusions were present in single cells, which were most likely macrophages. Positive cells were located in the superficial dermis of skin, in the interstitium of kidney and lung, and in the lamina propria and the submucosa of the intestine (Fig. 1). The presence of chlamydial inclusions was not associated with inflammatory infiltrates, but the frequently progressed autolysis allowed only limited evaluation of lesions. Findings are summarised in Table 4.

Chlamydial culture and bacterial culture from clinical samples

Because of low chlamydial DNA contents resulting in cycle threshold $(\mathrm{Ct})$ values above 30 , only few samples were processed for chlamydial culture. All cultures gave negative results (Table 3).

Frogs from this study (Table 3; cases no. 18-23) revealed different amounts of concomitant microbiota depending on the state of decomposition. The consistent bacterial microbiota was cultivated with varying intensity on SBA and Gassner agar and identified as Aeromonas hydrophila, Citrobacter freundii, Morganella morganii, Serratia plymuthica, Pseudomonas fluorescens, Alcaligenes faecalis, Chryseobacterium 


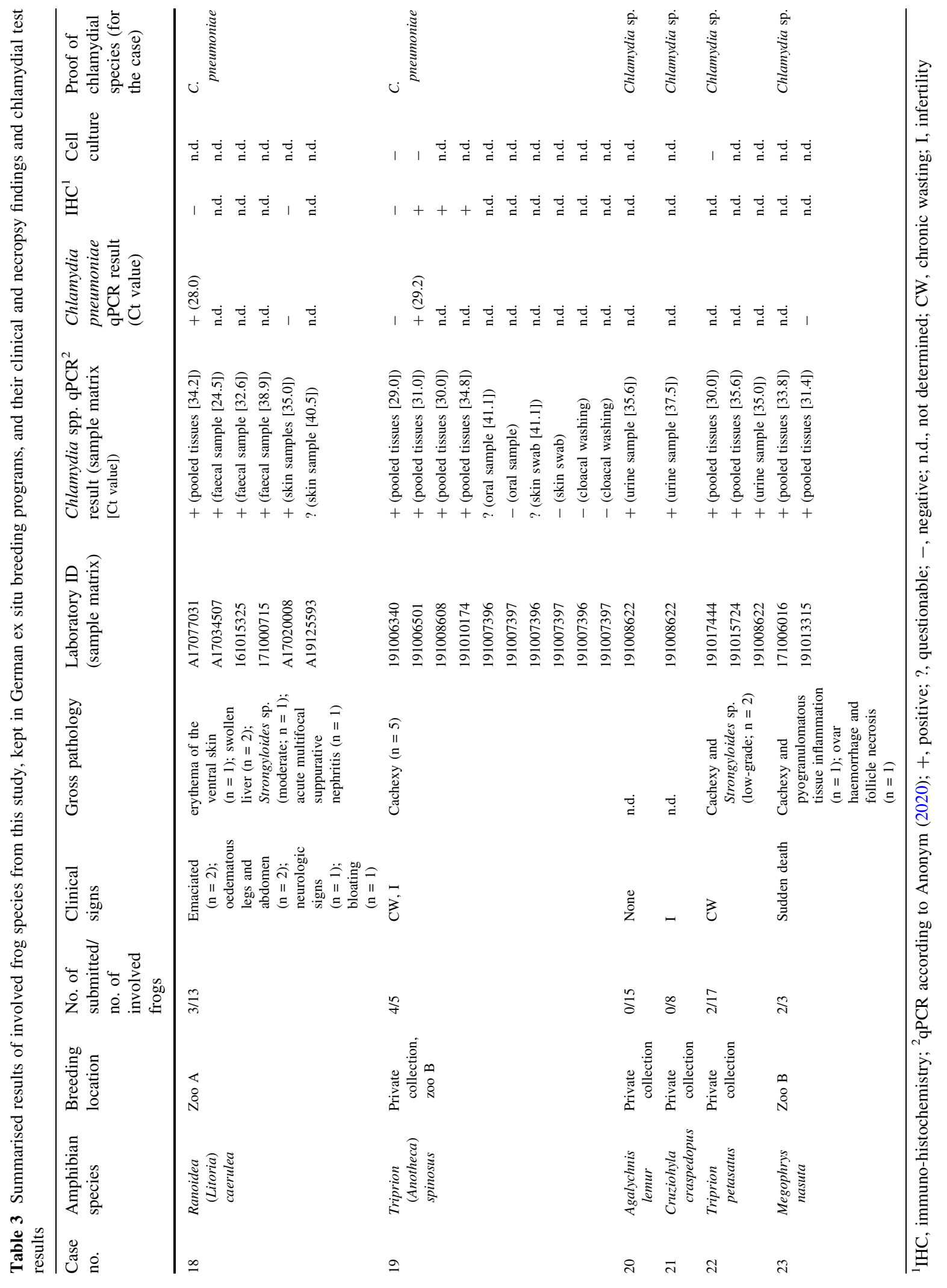




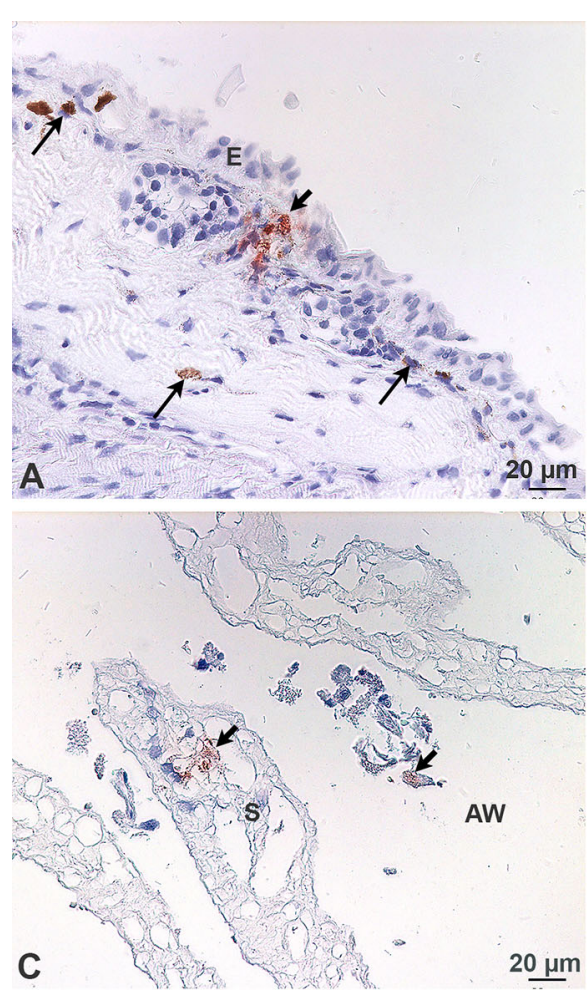

Fig. 1 a-d Chlamydial inclusions in Triprion spinosus (case no. 19). A. Several chlamydial inclusions (short arrow) in the superficial dermis adjacent to the epidermis (E); dark red, granular chlamydial inclusions are distinct from dark brown deposition of variably sized pigments (long arrows). B. Chlamydial inclusions (short arrows) in interstitial cells between renal

indologenes, Vagococcus fluvialis using MALDI-TOF MS, but without any particular proofs of Brucella spp. or Salmonella spp. (data not shown).

\section{Chlamydia detection by PCR and phylogenetic analysis}

Frogs from all three collections were found to be infected with $C$. pneumoniae, but definite species level identification was not attempted or did not give valid results in all cases. However, chlamydiae were detected at least once for each frog species in intra vitam or post mortem samples. Positive or questionable results were obtained from swabs taken from the skin and the mouth as well as from faeces and urine samples. Chlamydial tissue load as derived from $\mathrm{Ct}$ values was moderate to low (Ct 30-41) in most cases. An overview of Chlamydia PCR results and sample data is presented in Table 3.

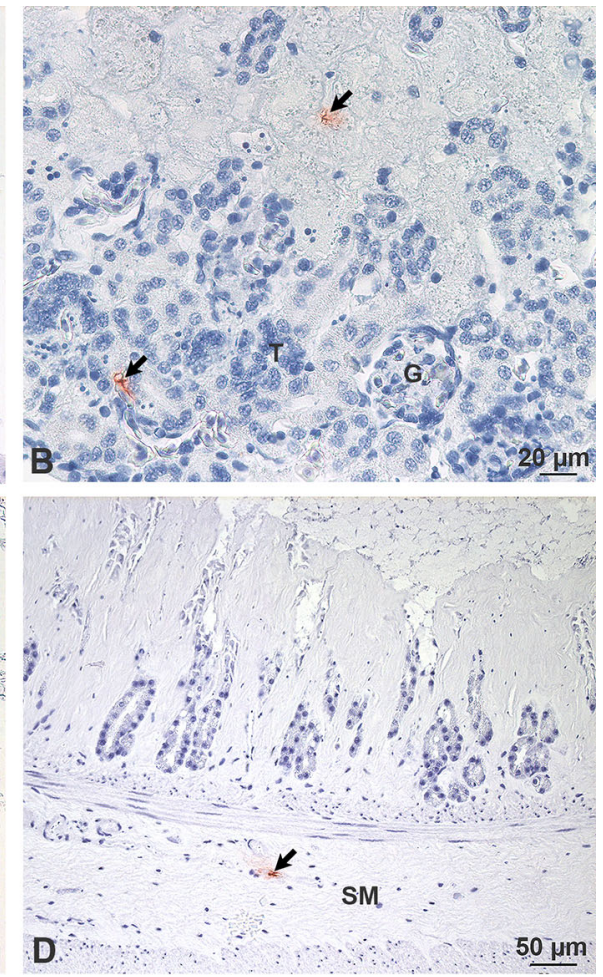

glomerula (G) and tubuli (T). C. Chlamydial inclusions (short arrows) in a pulmonary septum (S) and in a cell in the airway (AW). D. Chlamydial inclusion (short arrow) in the submucosa (SM) of the intestine. Immunohistochemistry for chlamydial LPS, counterstain hemalaun

Briefly, in the private collection chlamydiae were detected only by genus specific PCR and only in tissues of Triprion petasatus (s. Table 3; cases no. 20-22). However, T. spinosus from this holding were later diagnosed with C. pneumoniae in zoo B. In all 13 White's tree frogs from zoo A necropsied during 2016/2017 C. pneumoniae infection was diagnosed, either in faecal examinations, skin swabs or organ samples. Remarkably, all tests of swab samples or necropsied animals done in following years were negative for chlamydiae, except for one questionable skin swab. Equally, four out of five animals from the Triprion spinosus group quarantined in Zoo B showed positive results for chlamydiae in post mortem samples. In one sample from $T$. spinosus (see case 191006501; Table 3), a part of the 16S rRNA gene was amplified and sequenced (Accession No. MT487792). Sequence alignment showed 99.38-100\% similarity to C. pneumoniae $16 \mathrm{~S}$ rRNA 


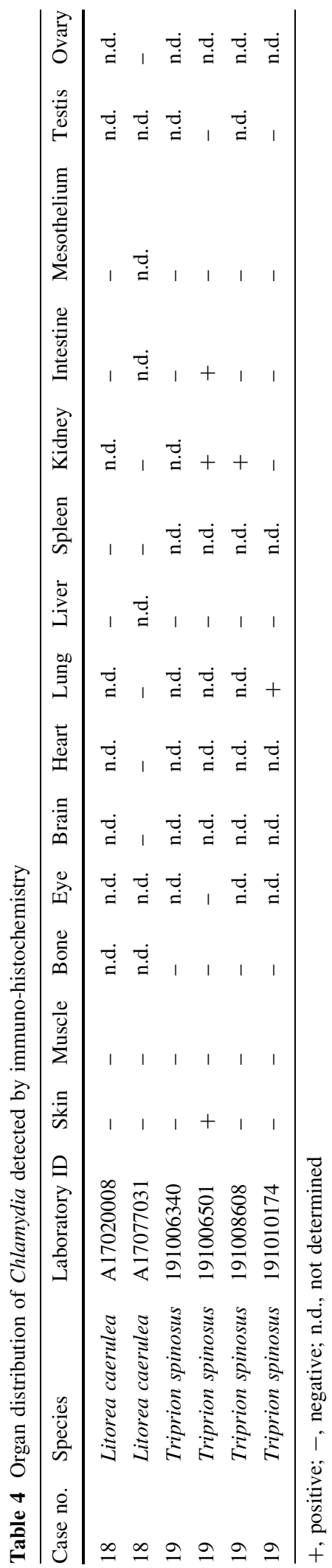

gene sequences deposited in GenBank. In a phylogenetic analysis, the sequence formed one cluster with other $C$. pneumoniae sequences from different sources, while other Chlamydia species obtained from other amphibians (Candidatus Amphibiichlamydia ranarum and Candidatus Amphibiichlamydia salamandrae) clustered together in another clade (Fig. 2).

Further testing

All samples were tested negative for the presence of chytrid fungus ( $B$. dendrobatidis, B. salamandrivorans) and ranavirus by PCR (data not shown).

\section{Discussion}

During the last 30 years, a number of studies have attempted to elucidate the role of chlamydial infections in amphibians (Table 1). The majority of cases involves the major amphibian order of frogs (Anura), but salamanders (Urodela) are also susceptible (Martel et al. 2012; Mutschmann 1998), whereas evidence in the order of caecilians (Gymnophiona) is still missing. Besides several acute mass mortality events with systemic infections, localised and chronic forms with involvement of central nervous system or lungs have been described (Berger et al. 1999; Blumer et al. 2007; Fratzke et al. 2019). Some amphibian species were found to be asymptomatically infected with chlamydiae. In the present study, the detection of chlamydiae by PCR or IHC was not correlated with specific morphological findings. In some cases, morphological alterations were attributed to other factors, for example parasitosis. However, clinical or gross pathological signs are generally not typical for chlamydiosis in amphibians (Wright 1996). Interestingly, a skin microbiome study in healthy salamanders detected chlamydiae as the fourth dominant phylotype and revealed that it makes up $24.3 \%$ of the total community (Bird et al. 2018). Potent anti-chlamydial dermaseptins have also been found in salamander skin. It was shown that they were highly effective against $C$. trachomatis, reducing the numbers of inclusionforming units and blocking novel infections in vitro (Bergaoui et al. 2013). Although infections do occur in the wild (Berger et al. 1999; Blumer et al. 2007; Martel et al. 2013), this could suggest a finely tuned balance mechanism under natural conditions. On the other 
hand and in the light of the worldwide amphibian decline, chlamydiae have been discussed to possess the potential to cause considerable impact on amphibian health (Martel et al. 2012). It remains to be determined, if and to which extent environmental or maintenance circumstances and cofactors influence the clinical outcome of amphibian chlamydiosis and asymptomatic chlamydial infections and whether such factors contribute to the microorganism's role as an obligate or facultative pathogen.

All previous studies have found chlamydiae only following post mortem examinations, but-like e.g. in reptiles (Rüegg et al. 2015; Taylor-Brown et al. 2015) and as obtained from skin, mouth, faecal and urine samples from the current study_intra vitam diagnosis is also possible in amphibians (Table 3).
Unfortunately, it was not possible to properly identify the involved chlamydiae at species level in all cases because tissue material had not been stored in retrospective cases. Likewise, bacterial load in tissue samples might have been too low in other cases, in which amplification or isolation in cell cultures were unsuccessful. It is tempting to speculate, that infection series within the same facility were caused by the same chlamydial species. C. pneumoniae has in the past been by far the predominant chlamydial species in amphibians and reptiles according to literature (Staub et al. 2018). This pathogen is usually found in humans and most adults become infected with $C$. pneumoniae at least once during their lifetimes (Aldous et al. 1992). Other susceptible host species are ruminants, pigs, horses, koalas and reptiles (Berger et al. 1999; Blumer

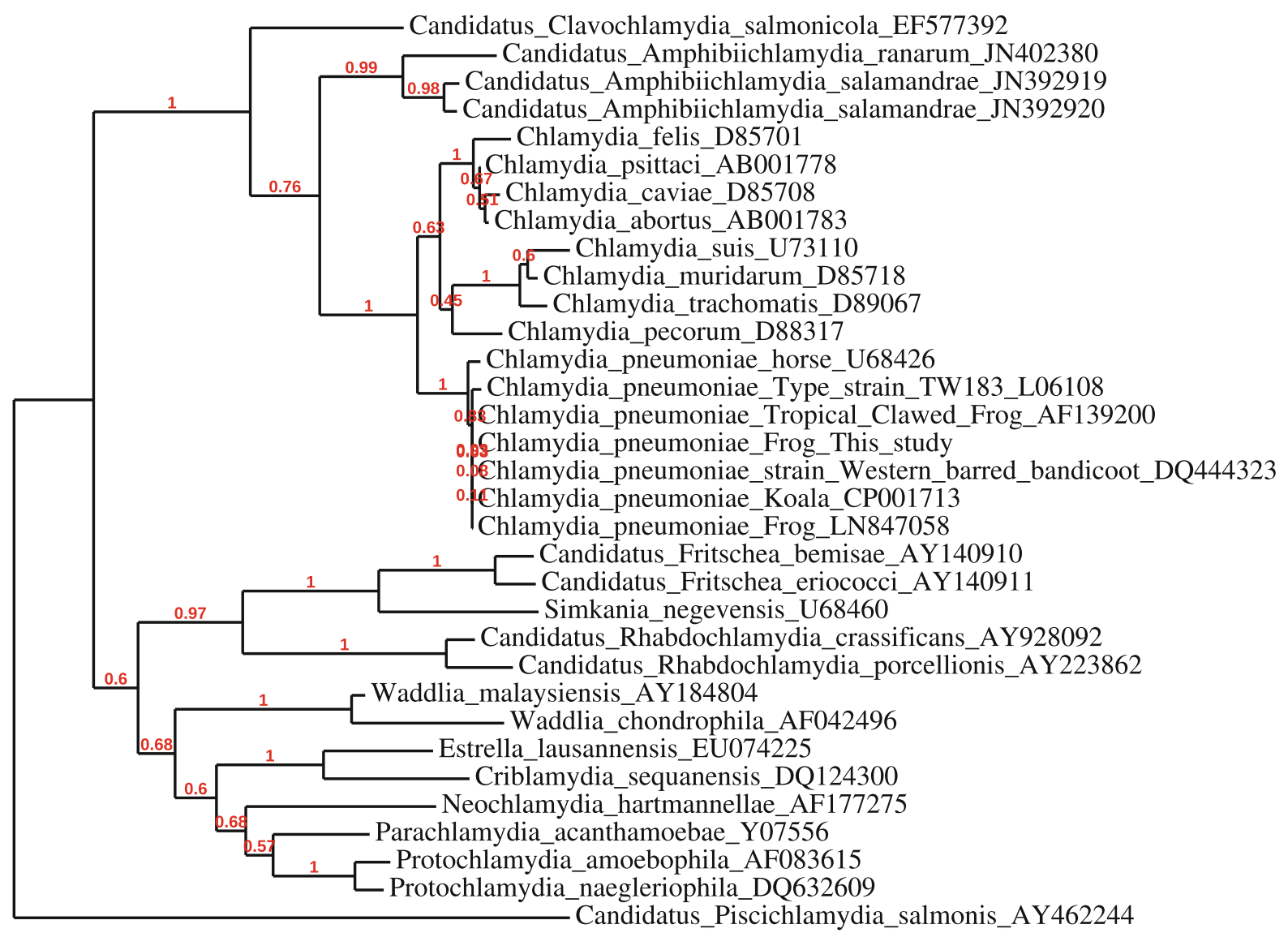

0.1

Fig. 2 Phylogenetic tree of near full-length 16S rRNA gene sequences obtained in this study and homologues of other chlamydiae. The analysis was carried out employing PhyML software using maximum-likelihood algorithm. Bootstrap values, given at the nodes, were obtained from 100 bootstrap replicates. The scale bar represents 0.1 substitution rate 
et al. 2007; Bodetti et al. 2002). Possibly, the spectrum of chlamydial species in amphibians is like in reptiles more diverse than known so far. There are other phylogenetically related, recently described reptilian taxa like C. serpentis and Candidatus C. testudinis, C. corallus and C. sanzinia which represent uncultivable or difficult to culture chlamydia (Laroucau et al. 2020; Staub et al. 2018; Taylor-Brown et al. 2016, 2017). In this context, the present report elucidates the importance of including routine testing on Chlamydia in amphibians. Culture-independent methods like metagenomics methods will support detection of uncultivable and hitherto unknown chlamydial species (Taylor-Brown et al. 2017).

In the present study, clinical signs like lethargy, anorexia, bloating as well as faded and sloughing skin were also observed (Table 2), but a very uncommon behaviour was regurgitation within 2 days after feeding that has previously only once been described for reptiles (Bodetti et al. 2002). Frogs in this study often lost their vitality, stopped calling and breeding and showed a state of chronic wasting until death after months. A poor body condition at necropsy accompanied by absent fat bodies and empty intestinal tracts was typical and has been described before (Blumer et al. 2007). In order to improve the health status several antimicrobial treatment regimens have been carried out in some of the here mentioned amphibian species groups. To avoid stress of daily handling of each single frog, bathing treatments with different medications were chosen. This apparently convenient application of antimicrobials has some pitfalls because pharmacokinetics and pharmacodynamics are largely unknown for the different species and most frogs tend to leave the body of water treatment. Therefore, a raining system used for breeding was utilised with prolonged contact times to ensure adequate absorption of the drugs through the skin and bladder wall. However, all the attempted treatments were unsuccessful because clinical signs did not improve and chlamydiae were still detected. Description of therapy regimes has rarely been included in papers published on amphibian chlamydiosis. Staub and colleagues found their reptilian isolates of $C$. serpentis and $C$. poikilothermis being temperature-sensitive and in vitro susceptible to tetracycline and moxifloxacin, but intermediate to resistant to azithromycin (Staub et al. 2018). Likewise, treatment was unsuccessful or associated with long-term neurologic deficits so that depopulation of tanks housing infected animals was used to control the disease (Fratzke et al. 2019). Rüegg et al. (2015) report treatment of seven snakes with chlamydiosis for up to 35 days with a daily intramuscular injection of marbofloxacin and could show on the one hand successful treatment confirmed by negative PCR, but on the other hand one loss and one therapy-resistant snake suggesting general need for implementation of safer and more efficient treatment protocols.

Previous studies have used a plethora of methods for the diagnosis of amphibian chlamydial infections (Table 2). Chlamydial culture was not successful in our case series, which might have been caused by low multiplicity of infection, possibly due to chronic state or by use of inadequate cell lines and culture conditions. Ct values above 32 are considered as an indicator for insufficient culture results (CS; personal experience). A low number of infected cells could be confirmed by IHC in some animals (Fig. 1).

Chlamydiae are prone to enter a phase of intracellular persistence when exposed to unfavourable conditions leading to remaining in a viable but noncultivable, one could also refer to it as a "dormant" state. This can explain unsuccessful antimicrobial treatment and in vitro cultivation. Hence, animals are reported to stay persistently infected for longer time periods and remain in an asymptomatic carrier status resulting in persistent, asymptomatic or minimally symptomatic, chronic infections. Those infections have the character of wasting diseases in the long term due to tissue damage in the pathogenesis of chlamydial disease (Borel et al. 2018; Panzetta et al. 2018). Eventually, clinically inapparent low-level chlamydial infections have been linked even with symbiosis (Horn 2008; Martel et al. 2013). Due to these unique features of "arrested" chlamydial replication and multiplication decreased detection sensitivity is to be expected.

Interestingly, further analysis particularly of the ompA and other genes of chlamydiae originating from poikilothermic animals revealed high similarity or even identical sequences to chlamydiae associated with respiratory and cardiovascular disease in humans (Bodetti et al. 2002; Cochrane et al. 2005). Meanwhile, with more in-depth whole genome sequencing (WGS)-based techniques becoming available, a growing body of evidence shows that human $C$. pneumoniae strains have once been zoonotically acquired and 
may have evolved from poikilothermic animals resulting in human-adapted chlamydiae becoming independent of the animal reservoir (Mitchell et al. 2010; Myers et al. 2009). Based on a multiple gene analysis from $30 \mathrm{C}$. pneumoniae strains from humans and animals (including amphibians) it was concluded that they belong to five genotypes (A-E), from which genotypes $\mathrm{A}, \mathrm{B}$, and $\mathrm{C}$ are among others associated with frogs (Mitchell et al. 2010). The authors hypothesise that a basal clade of amphibian isolates (cf. (Bodetti et al. 2002; Hotzel et al. 2001; Reed et al. 2000); genotype C) evolved to initially infect reptilian hosts and now represents the dominant clonal lineage of human infections (Mitchell et al. 2010). Interestingly, a second lineage has been identified with amphibian isolates (cf. Berger et al. 1999; Blumer et al. 2007; genotype A) as a starting point that evolved into two sub-lineages, one infecting Australian marsupials while the other branch has once more crossed the animal-human barrier to infect Australian Aboriginals (Mitchell et al. 2010). Similar results could be obtained by WGS analysis (Roulis et al. 2015).

\section{Conclusion}

The aim of the present study is to raise awareness about chlamydial infections in amphibians, especially frogs, and to suggest a targeted analysis in routine diagnostics. Among the Chlamydia spp. especially $C$. pneumoniae, but also so far unclassified species must be considered in the differential diagnosis of infectious amphibian diseases. Hence, we observed in our study an association between clinical signs of infertility and chronic wasting and pathological findings with infections caused by chlamydial organisms in frogs. Treatment should be only initiated, if chlamydia are confirmed as causative pathogens, since current treatment options have a poor prognosis due to possible persistence of this pathogen. Although $C$. pneumoniae is considered a 'monomorphic pathogen' with high intraspecific genetic similarity and humanto-human infections are frequently observed, $C$. pneumoniae isolates from amphibians do not seem to have a pronounced zoonotic potential.

Acknowledgements Open Access funding enabled and organized by Projekt DEAL. For their excellent assistance and support, we thank Katharina Engel, Theresa Glintzer, Björn Hebel, Jens Heinbächer, Andreas Jungck, Walter Lang, Sassan Schwarz and Marie-Luise Sonneborn. The Hessian State Laboratory is supported by Hessian Ministry for the Environment, Climate Change, Agriculture and Consumer Protection (HMUKLV). Triprion spinosus have been exported from Costa Rica issued by MINAE permit no. 042-2011SINAC. Therefore, we like to thank Prof. Dr. Gunther Köhler, Senckenberg, Leibniz Institution for Biodiversity and Earth System Research, Frankfurt, Germany.

Author's contributions TE conceived the study. NS, CG, TKW and TE were responsible for animal care, treatments, quarantine and disinfection. UK, AN, KR, IV and IS conducted gross pathology and histology. TE, AF, SH, CS, CI and RS performed the microbiological and molecular analyses. ELT conducted the IHC analysis. TE wrote the first draft of the report and all authors revised and approved the manuscript.

Funding This research received no specific grant from any funding agency in the public, commercial, or not-for-profit sectors.

Availability of data and material All data has been made fully available to the public.

\section{Compliance with ethical standards}

Conflict of interest The authors declare no conflict of interest.

Consent to participate All authors gave their consent to participate in this study.

Consent for publication All authors gave their consent to publish results from this study and to be listed as a co-author.

Ethics approval There is no ethical issue associated with this manuscript because the presented data was obtained during routine diagnostics in the frog species. They were not involved in any kind of animal experiment. According to competent authorities this kind of research does not require ethics approval or general approval with respect to German law.

Open Access This article is licensed under a Creative Commons Attribution 4.0 International License, which permits use, sharing, adaptation, distribution and reproduction in any medium or format, as long as you give appropriate credit to the original author(s) and the source, provide a link to the Creative Commons licence, and indicate if changes were made. The images or other third party material in this article are included in the article's Creative Commons licence, unless indicated otherwise in a credit line to the material. If material is not included in the article's Creative Commons licence and your intended use is not permitted by statutory regulation or exceeds the permitted use, you will need to obtain permission directly from the copyright holder. To view a copy of this licence, visit http://creativecommons.org/licenses/by/4.0/. 


\section{References}

Aldous MB, Grayston JT, Wang SP, Foy HM (1992) Seroepidemiology of Chlamydia pneumoniae TWAR infection in Seattle families, 1966-1979. J Infect Dis 166:646-649. https://doi.org/10.1093/infdis/166.3.646

Anonym (2020) Amtliche Methodensammlung und Falldefinitionen: Aviäre Chlamydiose. Friedrich-Loeffler-Institut, Institut für Molekulare Pathogenese. https://www. openagrar.de/receive/openagrar_mods_00059581

Bates KA, Clare FC, O’Hanlon S, Bosch J, Brookes L, Hopkins K, McLaughlin EJ, Daniel O, Garner TWJ, Fisher MC, Harrison XA (2018) Amphibian chytridiomycosis outbreak dynamics are linked with host skin bacterial community structure. Nat Commun 9:693. https://doi.org/10. 1038/s41467-018-02967-w

Bergaoui I, Zaïri A, Gharsallah H, Aouni M, Hammami A, Hani K, Selmi B (2013) The in vitro evaluation of anti-chlamydial and cytotoxic properties of dermaseptin S4 and derivatives: peptides from amphibian skin. Med Chem Res 22:6096-6104

Berger L, Volp K, Mathews S, Speare R, Timms P (1999) Chlamydia pneumoniae in a free-ranging giant barred frog (Mixophyes iteratus) from Australia. J Clin Microbiol 37:2378-2380

Bird AK, Prado-Irwin SR, Vredenburg VT, Zink AG (2018) Skin microbiomes of California terrestrial salamanders are influenced by habitat more than host phylogeny. Front Microbiol 9:442. https://doi.org/10.3389/fmicb.2018. 00442

Black Y, Meredith A, Price SJ (2017) Detection and reporting of ranavirus in amphibians: evaluation of the roles of the world organisation for animal health and the published literature. J Wildl Dis 53:509-520. https://doi.org/10.7589/ 2016-08-176

Blumer C, Zimmermann DR, Weilenmann R, Vaughan L, Pospischil A (2007) Chlamydiae in free-ranging and captive frogs in Switzerland. Vet Pathol 44:144-150. https:// doi.org/10.1354/vp.44-2-144

Bodetti TJ, Jacobson E, Wan C, Hafner L, Pospischil A, Rose K, Timms P (2002) Molecular evidence to support the expansion of the hostrange of Chlamydophila pneumoniae to include reptiles as well as humans, horses, koalas and amphibians. Syst Appl Microbiol 25:146-152. https://doi. org/10.1078/0723-2020-00086

Borel N, Greub G (2019) International Committee on systematics of prokaryotes (ICSP) subcommittee on the taxonomy of Chlamydiae. Minutes of the closed meeting, 5 July 2018, Woudschoten, Zeist, The Netherlands. Int J Syst Evol Microbiol 69:2606-2608

Borel N, Polkinghorne A, Pospischil A (2018) A review on chlamydial diseases in animals: still a challenge for pathologists? Vet Pathol 55:374-390. https://doi.org/10. 1177/0300985817751218

Boyle DG, Boyle DB, Olsen V, Morgan JA, Hyatt AD (2004) Rapid quantitative detection of chytridiomycosis (Batrachochytrium dendrobatidis) in amphibian samples using real-time Taqman PCR assay. Dis Aquat Org 60:141-148. https://doi.org/10.3354/dao060141
Cochrane M, Walker P, Gibbs H, Timms P (2005) Multiple genotypes of Chlamydia pneumoniae identified in human carotid plaque. Microbiology 151:2285-2290. https://doi. org/10.1099/mic.0.27781-0

Dereeper A, Guignon V, Blanc G, Audic S, Buffet S, Chevenet F, Dufayard JF, Guindon S, Lefort V, Lescot M, Claverie JM, Gascuel O (2008) Phylogeny.fr: robust phylogenetic analysis for the non-specialist. Nucleic Acids Res 36:W465-W469. https://doi.org/10.1093/nar/gkn180

Everett KD (2000) Chlamydia and Chlamydiales: more than meets the eye. Vet Microbiol 75:109-126. https://doi.org/ 10.1016/s0378-1135(00)00213-3

Everett KD, Bush RM, Andersen AA (1999) Emended description of the order Chlamydiales, proposal of Parachlamydiaceae fam. nov. and Simkaniaceae fam. nov., each containing one monotypic genus, revised taxonomy of the family Chlamydiaceae, including a new genus and five new species, and standards for the identification of organisms. Int J Syst Bacteriol 49(Pt 2):415-440. https://doi.org/10.1099/00207713-49-2-415

Fratzke A, Howard LL, Tocidlowski ME, Armien A, Oliveira F, Ritchie B, Berlin E, Snook E (2019) Chlamydia pneumoniae polioencephalomyelitis and ganglionitis in captive Houston toads (Anaxyrus houstonensis). Vet Pathol. https://doi.org/10.1177/0300985819844818

Homer BL, Jacobson ER, Schumacher J, Scherba G (1994) Chlamydiosis in mariculture-reared green sea turtles $(\mathrm{Ch}$ elonia mydas). Vet Pathol 31:1-7. https://doi.org/10.1177/ 030098589403100101

Honeyman VL, Mehran KG, Barker IK, Crawshaw GJ (1992) Bordetella septicaemia and chlamydiosis in eyelash leaf frogs (Ceratobatrachus guentheri). In: Proceedings of the Joint Meeting of the American Association of Zoo Veterinarians and the American Association of Wildlife Veterinarians 168

Horn M (2008) Chlamydiae as symbionts in eukaryotes. Annu Rev Microbiol 62:113-131. https://doi.org/10.1146/ annurev.micro.62.081307.162818

Hotzel H, Grossmann E, Mutschmann F, Sachse K (2001) Genetic characterization of a Chlamydophila pneumoniae isolate from an African frog and comparison to currently accepted biovars. Syst Appl Microbiol 24:63-66. https:// doi.org/10.1078/0723-2020-00016

Howerth EW (1984) Pathology of naturally occurring chlamydiosis in African clawed frogs (Xenopus laevis). Vet Pathol 21:28-32. https://doi.org/10.1177/030098588402100105

Huchzermeyer FW, Gerdes GH, Foggin CM, Huchzermeyer KD, Limper LC (1994) Hepatitis in farmed hatchling Nile crocodiles (Crocodylus niloticus) due to chlamydial infection. J S Afr Vet Assoc 65:20-22

Kuo CC, Stephens S, Bavoil PM, Kaltenboeck B (2011) Chlamydia. BMSAB

Laroucau K, Ortega N, Vorimore F, Aaziz R, Mitura A, Szymanska-Czerwinska M, Cicerol M, Salinas J, Sachse K, Caro MR (2020) Detection of a novel Chlamydia species in captive spur-thighed tortoises (Testudo graeca) in southeastern Spain and proposal of Candidatus Chlamydia testudinis. Syst Appl Microbiol 43:126071. https://doi.org/10. 1016/j.syapm.2020.126071

Martel A, Adriaensen C, Bogaerts S, Ducatelle R, Favoreel H, Crameri S, Hyatt AD, Haesebrouck F, Pasmans F (2012) 
Novel Chlamydiaceae disease in captive salamanders. Emerg Infect Dis 18:1020-1022. https://doi.org/10.3201/ eid1806.111137

Martel A, Adriaensen C, Sharifian-Fard M, Vandewoestyne M, Deforce D, Favoreel H, Bergen K, Spitzen-van der Sluijs A, Devisscher S, Adriaens T, Louette G, Baert K, Hyatt A, Crameri S, Haesebrouck F, Pasmans F (2013) The novel 'Candidatus Amphibiichlamydia ranarum' is highly prevalent in invasive exotic bullfrogs (Lithobates catesbeianus). Environ Microbiol Rep 5:105-108. https://doi. org/10.1111/j.1758-2229.2012.00359.x

Mitchell CM, Hutton S, Myers GS, Brunham R, Timms P (2010) Chlamydia pneumoniae is genetically diverse in animals and appears to have crossed the host barrier to humans on (at least) two occasions. PLoS Pathog 6:e1000903. https:// doi.org/10.1371/journal.ppat.1000903

Mutschmann F (1998) Detection of Chlamydia psittaci infections in amphibians using an immunofluorescence test [in German]. Berl Munch Tierarztl Wochenschr 111:187-189

Myers GS, Mathews SA, Eppinger M, Mitchell C, O’Brien KK, White OR, Benahmed F, Brunham RC, Read TD, Ravel J, Bavoil PM, Timms P (2009) Evidence that human Chlamydia pneumoniae was zoonotically acquired. J Bacteriol 191:7225-7233. https://doi.org/10.1128/jb.00746-09

Newcomer CE, Anver MR, Simmons JL, Wilcke BW Jr, Nace GW (1982) Spontaneous and experimental infections of Xenopus laevis with Chlamydia psittaci. Lab Anim Sci 32:680-686

Panzetta ME, Valdivia RH, Saka HA (2018) Chlamydia persistence: a survival strategy to evade antimicrobial effects in vitro and in-vivo. Front Microbiol 9:3101. https://doi. org/10.3389/fmicb.2018.03101

Reed KD, Ruth GR, Meyer JA, Shukla SK (2000) Chlamydia pneumoniae infection in a breeding colony of African clawed frogs (Xenopus tropicalis). Emerg Infect Dis 6:196-199. https://doi.org/10.3201/eid0602.000216

Roulis E, Bachmann N, Humphrys M, Myers G, Huston W, Polkinghorne A, Timms P (2015) Phylogenetic analysis of human Chlamydia pneumoniae strains reveals a distinct Australian indigenous clade that predates European exploration of the continent. BMC Genom 16:1094. https:// doi.org/10.1186/s12864-015-2281-y

Rüegg SR, Regenscheit N, Origgi FC, Kaiser C, Borel N (2015) Detection of Chlamydia pneumoniae in a collection of captive snakes and response to treatment with marbofloxacin. Vet J 205:424-426. https://doi.org/10.1016/j. tvj1.2015.05.007

Sachse K, Bavoil PM, Kaltenboeck B, Stephens RS, Kuo CC, Rossello-Mora R, Horn M (2015) Emendation of the family Chlamydiaceae: proposal of a single genus, $\mathrm{Ch}$ lamydia, to include all currently recognized species. Syst Appl Microbiol 38:99-103. https://doi.org/10.1016/j. syapm.2014.12.004

Schindarow L, Tonew E (1965) Cultivation of sheep abortion virus in tissue cultures of the liver of a cold-blooded animal (Lacerta viridis) [in German]. Zentralblatt fur Bakteriologie, Parasitenkunde, Infektionskrankheiten und Hygiene 1 Abt Medizinisch-hygienische Bakteriologie. Virusforschung und Parasitologie Originale 197:13-17

Staub E, Marti H, Biondi R, Levi A, Donati M, Leonard CA, Ley SD, Pillonel T, Greub G, Seth-Smith HMB, Borel N (2018) Novel Chlamydia species isolated from snakes are temperature-sensitive and exhibit decreased susceptibility to azithromycin. Sci Rep 8:5660. https://doi.org/10.1038/ s41598-018-23897-z

Taylor-Brown A, Ruegg S, Polkinghorne A, Borel N (2015) Characterisation of Chlamydia pneumoniae and other novel chlamydial infections in captive snakes. Vet Microbiol 178:88-93. https://doi.org/10.1016/j.vetmic. 2015.04.021

Taylor-Brown A, Bachmann NL, Borel N, Polkinghorne A (2016) Culture-independent genomic characterisation of Candidatus Chlamydia sanzinia, a novel uncultivated bacterium infecting snakes. BMC Genom 17:710. https:// doi.org/10.1186/s12864-016-3055-x

Taylor-Brown A, Spang L, Borel N, Polkinghorne A (2017) Culture-independent metagenomics supports discovery of uncultivable bacteria within the genus Chlamydia. Sci Rep 7:10661. https://doi.org/10.1038/s41598-017-10757-5

Vajana E, Widmer I, Rochat E, Duruz S, Selmoni O, Vuilleumier S, Aeby S, Greub G, Joost S (2019) Indication of spatially random occurrence of Chlamydia-like organisms in Bufo bufo tadpoles from ponds located in the Geneva metropolitan area. New Microbes New Infect 27:54-63. https://doi.org/10.1016/j.nmni.2018.11.006

Wilcke BW Jr, Newcomer CE, Anver MR, Simmons JL, Nace GW (1983) Isolation of Chlamydia psittaci from naturally infected African clawed frogs (Xenopus laevis). Infect Immun 41:789-794

Wright KM (1996) Chlamydial infections of amphibians. Bull Assoc Reptil Amphib Vet 6:8-9

Publisher's Note Springer Nature remains neutral with regard to jurisdictional claims in published maps and institutional affiliations. 